\title{
Os Tambores Silenciosos: a tríplice mimese, a relação autor/texto/ leitor, ficção e a realidade no jogo da intriga literária
}

\author{
Eliane Davila dos Santos* \\ Juracy Ignez Assmann Saraiva** \\ Ernani Cesar de Freitas***
}

\section{Resumo}

A literatura tem gerado interesse de estudiosos, desde Aristóteles (1966), os quais se dedicam a desvendar sua relação com o real e sua finalidade. A partir desse ângulo/contexto e com o objetivo de demonstrar como a representação mimética, por meio da narrativa, promove a convergência da mimese I, da mimese II e da mimese III, analisa-se a obra Os Tambores $\mathrm{Si}$ lenciosos $^{1}$. Como marco teórico, procura-se apoio na perspectiva da tríplice mimese de Paul Ricœur (1994) e nos postulados de Wolfgang Iser (2007) que conduzem ao entendimento do texto como um jogo entre o autor e o leitor. A análise direciona à percepção da mimese como uma representação da história, ao estabelecer, no jogo da encenação textual, a intriga em uma linha temporal, em que se integram a relação autor/texto/leitor, ficção e realidade.

Palavras chave: Representação. Tríplice mimese. Jogo do texto. Literatura. História.

* Doutoranda e Mestre em Processos e Manifestações Culturais pela Universidade Feevale (2015); Especialista em Gestão de Serviços pela Unisinos (2003); Gestão de Pessoas pela Unisinos (2001) e Administradora de Empresas pela Feevale (1997). Bolsista de doutorado pela Prosup/Capes em Processos e Manifestações Culturais na Universidade Feevale, dedicando-se às pesquisas da linguagem, comunicação e análise do discurso. E-mail: elianedavila@yahoo.com

* Doutora em Teoria Literária pela Pontifícia Universidade Católica do Rio Grande do Sul e realizou Pós-doutorado em Teoria da Literatura pela Unicamp, professora e pesquisadora da Universidade Feevale, onde coordena o Programa de Pós-Graduação em Processos e Manifestações Culturais. É pesquisadora em produtividade do CNPq. E-mail: jurazy@feevale.br

**** Doutor em Letras, área de concentração Linguística Aplicada (PUCRS/2006) com pós-doutoramento em Linguística Aplicada e Estudos da Linguagem - PUC-SP/LAEL (2011); Mestre em Linguística Aplicada pela (Unisinos/2002). Graduado em Letras - Português/ Inglês e respectivas Literaturas, pelo Centro Universitário La Salle (1999). Membro da Associação de Linguística Aplicada do Brasil (ALAB), da Asociación Latinoamericana de Estudios del Discurso (ALED). E-mail: ernanic@feevale.br

Data de submissão: abr. 2018 - Data de aceite: jun. 2018 http://dx.doi.org/10.5335/rdes.v14i2.8071 


\section{Introdução}

Estudos das obras literárias têm promovido diversas reflexões sobre as possibilidades de diálogo entre autor, texto e leitor e sobre o modo como os discursos literários inter-relacionam a instância da produção e a da recepção. Paralelamente, os pesquisadores investem, também, na elucidação de recursos que instalam a complexidade da linguagem como expressão da arte verbal, sendo valorizada a materialidade discursiva da obra literária, com o intuito de compreender o processo do "fazer" criativo do texto e de sua leitura. A relevância deste estudo, que se alicerça na perspectiva enunciativa, justifica-se pelo caráter interdisciplinar adotado, que estabelece correlações entre literatura e história, além de discutir a encenação do texto literário como um processo que transpõe as fronteiras do real e do ficcional.

A questão norteadora da análise evidencia que a representação mimética na obra Os Tambores Silenciosos denuncia, por meio da narrativa, fatos históricos brasileiros, ligando-os à realidade do leitor. Assim, analisa-se a narrativa de Josué Guimarães com o objetivo de demonstrar como sua representação mimética promove a convergência da mimese I, da mimese II e da mimese III.

Como marco teórico, procura-se apoio na perspectiva da tríplice mimese de Ricœur (1994) e nos postulados de Iser (2007), que conduzem ao entendimento do texto como um jogo textual entre au- tor e leitor. O motivo da escolha do corpus de pesquisa deve-se à materialidade discursiva que possibilita a compreensão do objetivo proposto. Para melhor organização do estudo, as seções estão assim dispostas: primeiramente, trata-se das questões relativas à tríplice mimese. $\mathrm{Na}$ segunda seção, mencionam-se as questões sobre o texto como um jogo. Segue-se com as questões metodológicas e, em seguida, com a seção de análise e resultados. Ao final, faz-se uma seção de considerações finais.

\section{A ampliação do conceito de mimese: o percurso do arco mimético na literatura}

[...] o tempo torna-se o tempo humano na medida em que é articulado de um modo narrativo, e que a narrativa atinge seu pleno significado quando se torna uma condição da existência temporal (RICEERR, 1994, p. 85).

Em sua acepção de narrativa, Ricœur (1994) retoma princípios da poética aristotélica, a que conjuga reflexões de Santo Agostinho sobre o tempo, e estabelece articulações entre os conceitos de mimese ${ }^{3}$ e $m y t{ }^{4}{ }^{4}$ de Aristóteles (1966). A introdução da perspectiva de Santo Agostinho (1996) às questões da poética aristotélica evidencia a preocupação com o tempo da narrativa. "Seguimos, pois o destino de um tempo prefigurado em um tempo refigurado, pela mediação de um tempo configurado" (RICCEUR, 1994, p. 87). 
Assim, para Agostinho constituem-se três tempos no tempo presente: a) um presente que recupera o passado; b) $o$ presente que projeta o futuro; c) o presente que já não é. Realça-se, dessa forma, que o conceito de mimese propõe uma expansão da concepção textual que abarca o transpassamento social. $\mathrm{O}$ texto, ou seja, a configuração da intriga, seria uma espécie de ponte entre um “[...] mundo prefigurado, que fornece inteligibilidade para o reconhecimento da narrativa, e a própria reconfiguração desse mundo prefigurado por intermédio das práticas de interpretação que transformam o texto e, assim, servem à própria ampliação dos significados partilhados que demarcam uma realidade" (CARVALHO; SANT'ANA, 2013, p. 227-238).

A partir daí, destaca-se o pressuposto de que a existência da inter-relação entre o tempo, a narrativa e a mimese apresenta-se como representação do processo criativo da produção e da recepção e se divide em três tempos: mimese I, mundo pré-configurado ou tempo do autor, mimese II, mundo configurado ou tempo do texto, e a mimese III mundo reconfigurado ou tempo do leitor. Consequentemente, a função da mimese I não é somente "[...] representar a ação, é primeiro pré-compreender o que ocorre com o agir humano, com sua semântica, com sua simbólica, com sua temporalidade" (RICEUR, 1994, p. 101).

A mimese I se constitui na representação da ação. Imitar ou representar é pré-compreender como ocorre o agir humano. O autor, nesse caso, deve conhecer o homem em suas manifestações semânticas, em seus simbolismos (o que transcende a compreensão da ação) e em sua temporalidade para que a tessitura da intriga seja costurada. O modo como a história se constitui sugere ao leitor a compreensão da significação do texto. Portanto, a pré-compreensão do mundo da narrativa é concebida a partir da ação em geral e de seus traços estruturais, levando-se em consideração os fins, os agentes, as motivações das circunstâncias, as interações e os resultados da construção da trama discursiva (RICEUR, 1994).

Na sequência, as afirmações sobre a mimese II abarcam reflexões sobre um mundo que poderia ser - reino do "como se" - cuja função é a mediação entre os acontecimentos ou episódios individuais em uma história; mediação entre os fatores heterogêneos que compõem a intriga; a mediação entre os caracteres temporais. Pode-se dizer que a mimese II evidencia uma relação cultural que é depreendida como inteligibilidade. "A criatividade do artista, neste sentido, não é original, ou seja, ele não é o ponto de origem da criação de sentidos, mas antes pode ser considerado um manipulador de significados culturais" (CARVALHO; SANT'ANA, 2013, p. 241). O ato configurante, ou seja, o texto, transforma-se na sucessão de acontecimentos, em uma totalidade significante, isto é, na configuração da mimese II, em que o leitor aprende a "ler o próprio tempo às 
avessas" (RICEUR, 1994, p. 106). Além disso, o ato configurante expressa traços de esquematização e de tradicionalismo da literatura, os quais evidenciam que a tradição e a inovação se conjugam na intriga.

O desenrolar da mimese III aponta para a ação do leitor que faz o reestabelecimento do tempo e do agir da narrativa. $\mathrm{O}$ cruzamento entre o mundo textual e o mundo do leitor oportuniza a reconfiguração do mundo pré-configurado, visto que a leitura não acontece descontextualizada da cultura e de horizontes simbólicos. $\mathrm{O}$ ato de ler, de interpretar, em um modelo espiral, permite que cada vez que o leitor lê um texto, uma nova atitude seja evocada. A leitura, nesse sentido, não é um ato passivo em que o leitor se torna um mero receptor da trilha da intriga, pois, nesse processo, $o$ leitor apoia-se em sua experiência ${ }^{5}$ para reconstruir o texto que lê.

Existe certo consenso entre a perspectiva de Ricœur (1994) e os postulados bakhtinianos $^{6}$, que revelam que "o signo não requer uma mera identificação, já que estabelece uma relação dialógica que comporta uma tomada de posição, uma atitude responsiva" (PONZIO, 2008, p. 190). Esse posicionamento permite compreender a complexidade da comunicação, visto que demanda um parceiro, um Outro $^{8}$, que não é simplesmente um sujeito passivo na enunciação. A construção de sentido, com base no signo ideológico, é relacionada à alteridade, ao dialogismo e à carga de valores que os sujeitos trazem consigo. Assim sendo, a proposta mimética “[...] não descreve um círculo, ou seja, não há um retorno ao mesmo ponto de partida, mas projeta uma espiral, visto que a configuração desloca o mundo prefigurado e a leitura desloca a configuração, reconfigurando o mundo da ação" (CARVALHO; SANT'ANA, 2013, p. 246).

A leitura, a partir de um mundo configurado, promove a transposição desse, ou seja, a leitura desloca o mundo textual, reconfigurando-o. O texto converte-se em significação na instância da interpretação, isto é, no nível da recepção, e o leitor se situa em um horizonte projetado e, nesse sentido, "o ouvinte ou o leitor recebe segundo sua própria capacidade de acolhimento que, também ela, define-se por uma situação ao mesmo tempo limitada e aberta a um horizonte de mundo" (RICEUR, 1994, p. 117). Há um elo que permite transformar o texto fictício em práticas sociais. "Os texto fictícios são responsáveis por ampliar as possibilidades de significar, entender e agir em uma realidade específica." (CARVALHO; SANT'ANA, 2013, p. 245). Ocorre uma ampliação dos horizonte de existência do leitor, pois, quando lê, ele se vê em um mundo em que poderia se projetar. Observa-se, também, que as influências entre a ficção e a historiografia comprovam a existência de referências cruzadas, quer dizer, os textos levantam os fatos históricos na narrativa e os conectam ao mundo real do leitor. 
Assim, na próxima seção, destaca-se o texto como uma proposta de jogo que provoca a interação entre o autor, o texto e o leitor e evidencia a orientação das expectativas do leitor pelos paradigmas recebidos e seu protagonismo no jogo do texto.

\section{O jogo encenado: o desafio textual de transpor as fronteiras do ficcional e do real}

O conceito de jogo, para explicar a relação autor, texto e leitor nas narrativas literárias tem sido profícuo para teorias que se valem de pressupostos que vão além dos pressupostos tradicionais de representação como referência a uma realidade pré-datada, segundo Iser (2007). No mundo moderno, cujos sistemas são abertos, a representação decai e o prisma performativo assume o primeiro plano textual. Trata-se de captar um mundo inteligível e de criar um mundo possível (ISER, 2007). É necessário pontuar que a narrativa, sob o ponto de vista discursivo, compreende o autor, o texto e o leitor. A narrativa "é o produto de ato interenunciativo, por intermédio do qual se institui a representação do real do texto, encenada por personagens situados e tempo e espaço determinados." (SARAIVA, 2009, p. 25). O jogo, nessa concepção, é um processo dinâmico e inter-relacional em que "os autores jogam com os leitores e o texto é o campo do jogo.” (ISER, 2007, p.107). A concepção do texto ficcional, nesse caso, é concebida não como uma realidade, mas como se fosse a realidade ou, de outro modo, um mundo encenado.

O sentido do texto se constitui a partir dos movimentos e contramovimentos realizados no jogo textual. Sob o prisma de Iser (2007), a significação do texto é um suplemento ${ }^{9}$ gerado pelo jogo, cuja produção vai se construindo pelos desempenhos diferentes dos receptores. O suplemento, portanto, é gerado na tensão entre o estabelecimento de sentido e a liberdade do jogo, que exige a manutenção da pluralidade de sentido. Igualmente, pode-se dizer que a palavra isolada não direciona para o que ela exatamente significa, pois "o que está implícito nas palavras depende de outras palavras, das condições em que foram enunciadas, de sua enunciação. É na situação de enunciação que as palavras revelam os pensamentos, as opiniões e as estratégias daquele que as emite." (CHARAUDEAU, 2016, p. 21). A plurivalência dos signos é que determina o caráter dinâmico das significações, dado que as muitas apreciações sociais se embatem e se enfrentam na mesma matéria e no próprio signo. $\mathrm{O}$ ato de enunciar pode, dependendo da orientação em que é abordado, ser heterogêneo, revelando o processo de significação aberto e infinito.

Define-se que, em nível estrutural textual, o significante fraturado ${ }^{10}$ "[...] invoca alguma coisa que não é pré-datada pelo texto, mas engendrada por ele, que 
habilita o leitor a dotá-lo de uma forma tangível." (ISER, 2007, p.110). O autor utiliza-se, dessa forma, de níveis extratextuais. Todo o processo de criação textual é uma transgressão àquilo que está instituído no texto. Tais princípios não negam a presença do mundo exterior, mas reconhecem que essa representação performática sempre será um desvio daquilo a que remete. $\mathrm{O}$ significante denota algo mais e, simultaneamente, ao conotar, transforma o que é denotado.

Outro ponto a ser considerado no jogo textual é a intertextualidade ${ }^{11}$, visto que todo texto é um mosaico de citações em que o autor propõe conexões dialógicas. Para interpretá-las e compreendê-las, o leitor precisa ter conhecimento e capacidade de interpretação, visto que o texto é a absorção e transformação de outros textos (SAMOYAULT, 2008) e os enunciados literários estão repletos de palavras de outros. "As palavras dos outros introduzem sua própria expressividade, seu tom valorativo, que assimilamos, reestruturamos, modificamos." (BAKHTIN, 2000, p. 314). Em alguns textos literários, utiliza-se a intertextualidade como um recurso, uma estratégia relevante que permite estabelecer correlações entre o mundo ficcional e o real, por meio de denúncias de fatos históricos, que podem ser ligados com a realidade do leitor. É pertinente comentar que é o leitor, diante do texto, que vai relacionar as informações textuais ficcionais com seu espaço e seu tempo. Além disso, "sempre há um elemento no papel do jogo que escapa do domínio do jogador" (ISER, 2002, p. 114). Assim sendo, o jogo pode ser realizado seja para amplificar, seja para delimitar o grau de incontrolabilidade.

O jogo encenado no texto não é um espetáculo em que o leitor é visto como um receptor, mas como um acontecimento com o qual o leitor interage. O jogo oferece ao leitor três modos de jogar: a) o modo semântico: busca da compreensão e sentido no texto; b) o modo da experiência: abertura para o que não é familiar; c) o modo do prazer: a busca do deleite. Jogar o jogo do texto, portanto, é transpor as fronteiras da encenação, para evidenciar a maneira de compor essa encenação e o alcance do "outro" pelo leitor.

\section{Rotas de os Tambores silenciosos}

A escolha da obra (corpus) ${ }^{12}$ deu-se em função da materialidade discursiva, visto que promove reflexões sobre a representação mimética por meio da narrativa, trazendo uma denúncia sobre acontecimentos da história do Brasil, que podem interligar-se com a realidade do leitor. Seguindo o aporte teórico do estudo, organizam-se as categorias apresentadas na Figura 1, que concebem o dispositivo que referencia a análise do corpus. 
Figura 1 - Dispositivo epistemológico de análise

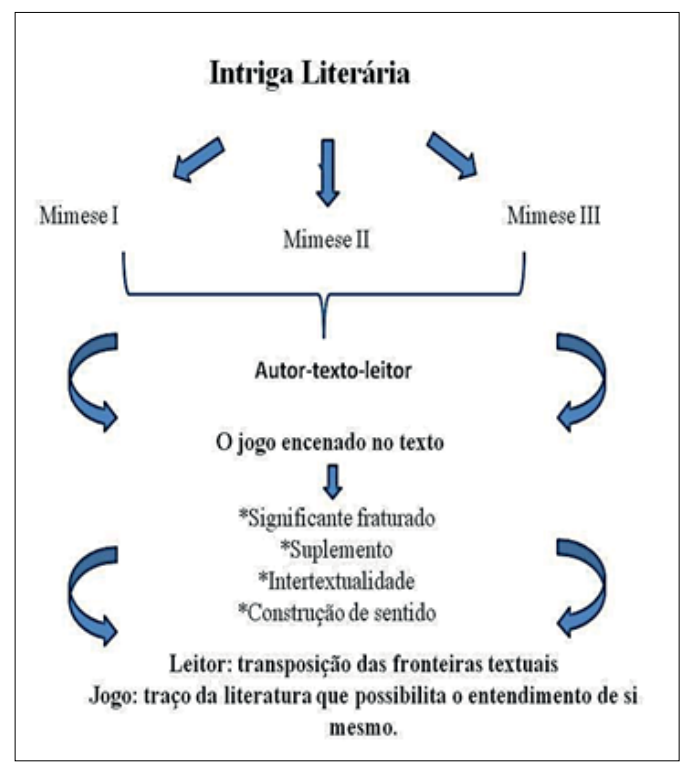

Fonte: Elaborado pelos autores

Começando pelo dispositivo epistemológico mostrado na Figura 1, criam-se categorias para a análise da obra $O s$ Tambores Silenciosos de Josué de Guimarães.

a) A tríplice mimese: a categoria teórica evidencia a ampliação do conceito de representação mimética e dá relevo à inter-relação autor, texto e leitor na intriga literária. No conceito de mimese há um desdobramento significativo proposto pelos postulados teóricos de Ricœur (1994), que a configura em Mimese I, Mimese II e Mimese III.

b) O jogo do texto encenado: a categoria apresenta conceitos que refletem sobre o texto literário como um jogo de encenações, cujo suplemento ${ }^{13}$ apresenta um significado fratura$\mathrm{do}^{14}$ e cujas estratégias auxiliam na construção de sentido pelo leitor. Alicerça-se essa categoria teórica nos fundamentos teóricos de Iser (2002). A categoria aponta para a determinação de que o leitor transpõe as fronteiras entre o ficcional e o real e, dessa forma, oportuniza a compreensão da literatura como forma de entendimento de si mesmo.

O estudo está organizado da seguinte maneira: apresenta-se a obra literária Os Tambores Silenciosos. Logo após, identifica-se a análise de resultados mediante as categorias teóricas: a) A tríplice mimese e b) O jogo do texto encenado. No final, apresentam-se as considerações finais do estudo.

\section{Os tambores silenciosos: a trilha do texto}

Por nos conceder ter a ausência como presença, o jogo se converte em um meio pelo qual podemos nos estender a nós mesmos. Essa extensão é um traço básico e sempre fascinante da literatura. Inevitavelmente, se põe a questão por que dela necessitamos. A resposta a esta pergunta poderia ser o ponto de partida para uma antropologia literária (ISER, 2007, p. 118).

A obra Os Tambores Silenciosos foi escrita em 1975, porém, publicada por Josué Guimarães em 1977. O romance recebeu o Prêmio Érico Veríssimo de Romances, oferecido pela Editora Globo, no ano de sua publicação.

O autor constrói sua narrativa sobre a cidade imaginária de Lagoa Branca, próxima a Passo Fundo, situando-a nos 
sete primeiros dias de setembro de 1936. O texto revela as práticas cotidianas dessa pequena cidade fictícia do interior do Rio Grande do Sul, em uma época que antecipava o estabelecimento do Estado Novo ${ }^{15}$ por Getúlio Vargas.

A intriga desenvolve-se em torno do coronel João Cândido, que tem o desejo de construir uma comunidade ideal. Além de proibir aos cidadãos o acesso à comunicação externa à cidade, inicia uma série de atos violentos com o apoio da polícia local, os quais vão desde a coça de estudantes à exterminação de indigentes da cidade. O pânico toma conta de Lagoa Branca quando pássaros de tecido, (feitos em segredo por Maria da Glória, a mais jovem das sete irmãs da família Pilar, se espalham pela cidade). Essa personagem é cega, mas parece ser a única que enxerga as atrocidades comandadas pelo prefeito de Lagoa Branca. O esclarecimento das mentiras, que existem na cidade, expõe o caráter de delação da obra, uma vez que os mencionados pássaros negros, a sequência de boicotes e acusações evidenciam a vulnerabilidade dos políticos e conduzem à derrota de seus projetos, enquanto o prefeito se suicida. A história é apresentada por um narrador heterodiegético, a partir da percepção das irmãs solteironas da família Pilar, que, utilizando-se de um binóculo, possibilitam ao leitor contemplar o desenrolar das ações no espaço de Lagoa Branca.

Após a apresentação de Os Tambores Silenciosos, inicia-se a análise da primeira categoria eleita, na busca do cumprimento do objetivo deste artigo:

a) A tríplice mimese: a acepção de mimese de Ricœur (1994) orienta a análise dessa categoria. Os Tambores Silenciosos sugere abranger o tempo da intriga apoiado nas três mimeses propostas pelo autor. Primeiramente, percebe-se o tempo pré-configurado, isto é, o tempo do autor na narrativa. A compreensão da mimese I alicerça-se na decisão de autor de apresentar a narrativa a partir de eventos ocorridos no Brasil, no ano de 1936. As personagens da intriga são pré-configuradas como homens medíocres, dominados pela ganância, mulheres infiéis e policiais impiedosos. A trama representa os dramas e as dificuldades do povo diante da política autoritária dos governantes.

O contexto social da época da juventude do autor, fortemente marcado pela ditadura brasileira, leva-o a transferir e refletir sobre sua experiência no texto. $\mathrm{O}$ processo transforma a realidade em uma obra de arte. Toma-se, como exemplo, a personagem do prefeito de Lagoa Branca, o coronel João Cândido. Ancorado em códigos culturais e simbólicos do contexto histórico ditatorial, o autor fornece as regras para que o leitor se aproxime da obra e possivelmente compreenda a realidade que a precede e passe a refletir sobre ela. Cabe lembrar que o autor se utiliza das irmãs Pilar, para preconizar a maior parte dos fatos que ocorrem na história: por meio do binóculo das irmãs, a trama é tecida. É importante ressaltar 
que o olhar das mulheres vai até onde o binóculo pode alcançar. Sem o binóculo, as personagens teriam pouco a dizer. $\mathrm{O}$ autor, além das irmãs Pilar, dispõe de um narrador em terceira pessoa, que situa o romance em um tempo e espaço, à primeira vista, afastado da contemporaneidade. As estratégias por ele utilizadas denunciam um cenário opressor e autoritário, de que o autor se serve para interligar o momento ditatorial por ele vivido com o do texto ficcional, conjugando a época do Estado Novo e a Ditadura de 1964.

O Estado novo foi um regime ditatorial, que se instalou sob o comando de Getúlio Vargas, que se estendeu de 1937 a 1945 e foi marcado pela censura, pelo autoritarismo e pela centralização do poder. Semelhante ao Estado Novo, a Ditadura Militar que se estendeu de 1964 a 1985, também foi um regime totalitário que, durante seus 21 anos, impôs restrições à imprensa e aos opositores que fossem contrários ao regime vigente. Portanto, no texto, ao representar ficcionalmente a ditadura, o escritor transpõe o momento histórico do Estado Novo, que, entretanto, se expande para introduzir a reflexão sobre a Ditadura Militar de 1964, momento da produção do texto e de sua recepção inicial, como se comprova pela premiação da obra.

Seguindo o esquema da mimesis de Ricœur (1994), a mimese II é entendida como reino do "como se". Os Tambores Silenciosos tornam-se, na mimese II, o texto, ou seja, a própria produção poética do autor. Compreendidas as intenções pactuadas na mimese I, o leitor encontra, na mimese II, o processo de criação do autor concretizado. No romance, a história acontece em um tempo e espaço definidos: a intriga se desenrola nos sete primeiros dias do mês de setembro de 1936, na cidade de Lagoa Branca, no Rio Grande do Sul. A atitude ditatorial do prefeito, ao proibir a circulação de jornais e dos rádios na cidade, impôs novas diretrizes aos pacatos costumes da cidade interiorana. Os preparativos, que são feitos para a celebração do sete de setembro, que servem apenas à realização pessoal do prefeito, deixam pistas ao leitor sobre os acontecimentos da história. Embora o romance Os Tambores Silenciosos tenha um tempo cronológico linear, a produção poética permite ao leitor ler o tempo às avessas, visto que 0 texto torna-se ato configurante, ou seja, possibilita que o leitor siga a narrativa, recuperando seus acontecimentos.

A história desnuda os hábitos dos moradores da cidade e seus comportamentos: polícia corrupta, mulheres infiéis e personagens como as irmãs Pilar, que bisbilhotam a vida alheia por meio de um binóculo. A única das sete irmãs que destoa é a mais moça e, somente, no final da história, fica-se sabendo que é cega e que fora ela que construíra os pássaros de tecido que povoam a cidade, pressagiando algo de mau para seus habitantes. À proporção que as aves de tecido ocupam a cidade, o governo do município torna-se mais coercitivo. 
Mendigos são retirados da cidade e mortos. A população, em resistência aos processos tirânicos do governo, alertada pelos jovens, não comparece aos festejos de sete de setembro. Depois de saberem que era o próprio prefeito que censurava toda comunicação com outras cidades, as vítimas da repressão são libertadas da prisão. Ao final, a irmã Pilar cega, morre. Além disso, o prefeito suicida-se, em meio a uma chuva torrencial, no centro da cidade. A mimese II, portanto, configura-se como uma ponte que se abre para o leitor, isto é, a mimese III.

Na mimese III, o leitor faz o reestabelecimento do tempo e do agir da narrativa (RICEUR, 1994). Assim, como instância da recepção, o leitor exerce a função interpretativa com a obra Os Tambores Silenciosos, fazendo a intersecção entre o mundo do texto e seu mundo. $\mathrm{O}$ fato de as personagens não terem acesso a jornais e outros meios de comunicação, como rádio, assim como o extermínio dos mendigos da cidade, dão pistas sobre o período da Ditadura, quando Josué Guimarães escreveu o livro, instaurando reflexões sobre esse momento, historicamente demarcado.

Na mimese III, o leitor faz a reconstituição do tempo e do agir das personagens da pequena cidade de Lagoa Branca. O processo interpretativo do leitor parte da verossimilhança que o autor constrói na narrativa: as ações do prefeito autoritário, os conchavos entre os políticos e a polícia da cidade, a censura velada, o povo amedrontado, os jovens punidos, enfim, são elementos que permitem a recomposição do texto a partir da experiência do leitor.

A narrativa Os Tambores Silenciosos promove a conscientização do leitor sobre a ditadura. $\mathrm{O}$ autor, no momento da construção textual, precisava camuflar, nas ações das personagens, o que realmente queria dizer, pois corria o risco de ter o livro censurado ou até mesmo de ser preso. Entretanto, quem lê o livro percebe que ele foi uma estratégia do autor para presentificar o momento histórico. As analogias apresentadas no texto, como a personagem cega, os pássaros que ela produz, a cidade perfeita são pistas do autor que se relacionam à presentificação do real, concebida pelo processo da mimese. Não há uma fidelidade aos fatos históricos, pois se trata de um texto fictício, mas é por meio dele que o autor denúncia a estrutura autoritária de poder. Consequentemente, a obra $O s$ Tambores Silenciosos, embora ficcional, está ligada à realidade do leitor.

As ações das personagens favorecem a análise e estabelecem diálogos com o texto, segundo os postulados bakhtinianos (PONZIO, 2008), permitindo ao leitor compreender uma história subjacente. Realiza-se, assim, a convergência entre a mimese III e a Mimese I, sendo a mimese II a ponte que realiza esse encontro.

Assim, na sequência, passa-se às reflexões sobre a segunda categoria de análise que sugere que o texto é um jogo de encenações: 
b) O jogo do texto encenado: a concepção de Iser (2007) contribui para a análise do romance citado, pois, centrando-se na relação autor, texto e leitor, evidencia que Os Tambores Silenciosos é o produto de ato interenunciativo, por intermédio da encenação dos personagens situados em tempo e espaço determinados (SARAIVA, 2009). A cidade de Lagoa Branca é fictícia, porém, é como se fosse uma cidade real do Estado do Rio Grande do Sul. As personagens que ali habitam, as imãs Pilar, o prefeito, os homens medíocres dominados pela ambição, as mulheres infiéis, os policiais violentos encenam o mundo ficcional e propiciam ao leitor a compreensão da pluralidade dos signos e sua capacidade simultânea de denotar e conotar. Observa-se que a materialidade discursiva da obra oportuniza ao leitor a alternativa de compreender os signos de forma que o significante fraturado transgrida o significado denotado.

A passagem que narra a presença de pássaros negros que, enigmaticamente, invadem a cidade de Lagoa Branca, sob a perspectiva de Iser (2007), pode ser considerada, conotativamente, como um mau presságio ou como a morte da democracia. Considera-se que, para encenar o texto ficcional, o autor apresenta os pássaros como uma forma de sanção aos políticos e a suas ações ditatoriais e pode ser percebida pelo leitor atento. Dessa forma, o leitor poderá depreender esse algo a mais $^{17}$ que permeia a tessitura textual. Logo, a construção do sentido textual vai depender do entendimento do leitor (CHARAUDEAU, 2016) que, a partir de suas vivências, poderá ou não capturar a mensagem que o autor tentou construir. Essa plurivalência dos signos leva a um universo aberto de significações, e a intertextualidade (SAMOYAULT, 2008), compreendida como a relação explícita ou apenas sugerida com outros textos ou com campos discursivos, também se faz presente na obra, abrindo novas possibilidades de significação.

Nesse sentido, o próprio título da obra, Os Tambores Silenciosos, remete à Ação Integralista Brasileira (AIB), partido político liderado por Plínio Salgado, que disseminou a cultura integralista no Brasil $^{18}$. Entre os rituais desse movimento, incluía-se o denominado "Noite dos tambores silenciosos", ocasião em que os "camisas verdes" soavam tambores durante três minutos, em homenagem aos combatentes mortos do grupo, enquanto um dos presentes lia o poema de Jaime de Castro, cujo título era também o da cerimônia.

O título da narrativa constitui um insulto ao movimento integralista, que se opunha ao governo de Getúlio Vargas, embora seguisse uma orientação fascista, visto que, na celebração de sete de setembro, em Lagoa Branca, os tambores não soaram, ainda que os integralistas neles batessem: "Que diabo, esses tambores não tocam?” (GUIMARÃES, 2011, p. 200). Assim, os integralistas, que apoiaram o prefeito João Cândido, foram ridicularizados perante o pequeno público que compareceu ao evento, em meio à 
chuva torrencial e aos pássaros negros que haviam tomado a cidade. Com efeito, pode-se dizer que o não tocar dos tambores sugere a tomada de uma atitude responsiva ativa (PONZIO, 2008).

Utilizando a intertextualidade para melhor compreender esse momento da história, evidencia-se, também, que, em rituais da igreja católica, da Sexta-feira Santa, até o domingo de Páscoa, os sinos se calam, como sinal de reflexão e de posicionamento responsivo frente aos dogmas da igreja ${ }^{20}$. Em Os Tambores Silenciosos, a analogia pode ser entendida como sinal da morte e do vazio que a cidade vive ante as barbaridades que lá acontecem, manifestando-se o protesto pelo silêncio dos tambores e pelos pássaros negros.

$\mathrm{Na}$ mesma linha de pensamento, o que também deve ser destacado em $O s$ Tambores Silenciosos, é a cegueira de Maria da Glória. O autor, embora mencione sua cegueira somente no final do romance, deixa pistas de que havia algo a ser questionado sobre ela como se constata no fragmento textual: Maria Celeste apagou a luz da cozinha, deixou a mais nova delas tirando a mesa e lavando a louça e as panelas, e foram todas para a sala (GUIMARÃES, 2011, p. 16). A cegueira, em culturas ocidentais, está, muitas vezes, ligada conotativamente, a sentidos misteriosos. Também pode conotar a visão de algo mais ${ }^{21}$, ou seja, a cegueira pode sugerir a capacidade de enxergar além da visão normal. $\mathrm{Na}$ mitologia grega, o cego Tiresias auxilia
Édipo a desenredar uma situação enigmática, o que permite correlacioná-lo à construção da personagem Maria da Glória no texto, uma vez que reforça o fato de ela poder ter um vínculo com o sobrenatural, isto é, os pais, que já eram mortos. Maria da Glória dedica sua vida a confeccionar bichos de pano, inclusive os pássaros negros que parecem ter vida e, ao final da narrativa, descobre-se que eram os que tinham invadido a cidade.

A cegueira, vista como um recurso do autor para estabelecer correlações entre ficção e realidade, proporciona subsídios para que o leitor reflita sobre a importância das ações da personagem Maria da Glória na intriga. Na perspectiva de Iser (2007), a interação do leitor como o texto vai propiciar o jogo textual. A cega, em $O s$ Tambores Silenciosos, aquela personagem que tem uma deficiência física, é a única que enxerga as atrocidades dos políticos, o abuso e a censura que os cidadãos de Lagoa Branca estão vivenciando. $\mathrm{O}$ autor, com maestria, constrói a personagem, uma mulher que não vê, mas que é a única habitante da cidade que compreende a situação. Embora seja cega, ela enxerga. $\mathrm{E}$, ironicamente, pode-se dizer que quem vê, não enxerga. Verifica-se que o autor joga com metáforas textuais de significações contrárias, o que conota uma visão esclarecida sobre os fatos que ocorrem em Lagoa Branca. Assim, o leitor é convidado a jogar o jogo do texto, a fazer parte da peça encenada e a interagir com as estratégias, as metáforas relacionadas aos fatos históricos, que, apresentadas na 
obra ficcional, lhe permitem estabelecer correlações com a realidade.

\section{Considerações finais}

A narrativa de Os Tambores Silenciosos auxilia o leitor a transpor as fronteiras entre o ficcional e o real e suscita reflexões sobre as relações entre autor, o texto que ele produz - como resultado de um posicionamento crítico - e as estratégias que exigem a intervenção do leitor. A linguagem é complexa, assimétrica e, dentro do processo do fazer criativo, oferece terreno fértil para que a obra literária seja desvelada e proporcione, ao leitor, por meio do processo da mimese III, seu encontro com a alteridade, ao integrar tempos distintos: o do presente da recepção com o do passado da produção do texto e com o da encenação dos eventos.

A questão norteadora do artigo demonstra que a representação mimética, que estabelece a convergência da mimese I, da mimese II e da mimese III, na obra Os Tambores Silenciosos denuncia, por meio da narrativa, acontecimentos históricos brasileiros, ligando-os à realidade do leitor.

A análise possibilita reflexões sobre a construção mimética e sobre o jogo de encenações na obra literária e pode colaborar com futuras investigações sobre os aspectos teóricos mobilizados. Dessa forma, pergunta-se: qual é a função da personagem Maria da Glória dentro da intriga? O que ela tem a dizer? As trilhas foram traçadas durante o percurso da análise e encontram respaldo no final da leitura da obra, por meio da qual se compreende que o leitor pode se colocar no lugar da personagem. Isso significa que a mimese opera um deslocamento do eu, uma vez que ela instala o ponto que denuncia as crueldades por meio do texto ficcional, o qual é adotado pelo leitor. Diante do jogo do texto encenado, o leitor faz a leitura às cegas, de acordo com as estratégias e recursos utilizados pelo autor, porém, ao final da obra, encontra a clareza, a iluminação e retoma sua visão. Eis que a obra literária não deve ser "um ponto final" para o leitor, mas a ponte para que ele recupere $o$ passado e projete o futuro.

The Silent Drums: the triple mimesis, the relation author / text / reader, fiction and reality in the game of literary intrigue

\section{Abstract}

Since Aristotle's day, men seek to understand texts and art works. In this context, one observes that literary production has been interesting philosophers that dedicate themselves to unveil the purpose of literature in the world. It is from this point of view, and aiming to demonstrate how mimetic representation, by means of its narration, promotes the convergence of mimesis I, mimesis II and mimesis III that one analyses the work Os Tambores Silenciosos (The Silent Drums). As theoretical framework, 
one seeks support in Paul Ricœur's (1994) triple mimesis perspective as well as in Wolfgang Iser's (2007) postulates, which lead to understanding texts as a game between author and reader. The research corpus corresponds to Josué Guimarães' already mentioned novel The Silent Drums. The analysis directs to the perception of mimesis as a representation of History when it establishes, in the literary text performance, "the plot" within a temporary line in which the relation author/text/reader, fiction and reality get integrated.

Keywords: Representation; Triple mimesis; Text game; Literature; History.

\section{Notas}

1 A obra Os Tambores Silenciosos, de Josué Guimarães, recebeu o prêmio Érico Veríssimo de Romance em 1975.

2 Perspectiva aristotélica que equivale ao discurso literário.

3 Imitação, representação do agir humano (RICEUR, 1994).

4 Processo de composição da intriga, ou seja, da construção da narrativa (discurso).

5 Verossimilhança.

6 Mikhail Bakhtin foi um dos filósofos russos mais importantes do século XX. Nasceu em 1895 e faleceu em 1975. "Seu nome é referência fundamental para diversas teorias que, de uma forma ou de outra, discutem e problematizam a questão da comunicação hoje. As suas maiores contribuições foram fundamentais para $o$ desenvolvimento dos estudos da linguagem e da estética, campos nos quais a sua obra é mais conhecida e reconhecida" (RIBEIRO; SACRAMENTO, 2010, p. 9).

7 Adotar uma atitude responsiva ativa significa dizer que o ouvinte recebe e compreende os signos e pode concordar ou discordar com o enunciado concreto.

8 O leitor da obra literária.

9 Trata-se de um "algo a mais" engendrado no texto.
10 O significante fraturado é o menor espaço do jogo textual. Ele pode ser, simultaneamente, denotativo e figurativo (ISER, 2007).

11 Termo criado pela russa Julia Kristeva a partir dos estudos que ela faz da teoria de Bakhtin.

12 Obra literária Os Tambores Silenciosos de Josué Guimarães cuja publicação original ocorreu em 1977.

13 Suplemento é significado engendrado por meio do próprio jogo textual.

14 Sentido denotativo e conotativo.

15 O Estado Novo refere-se ao governo de Getúlio Vargas - 1937 a 1945. Esse momento histórico ficou conhecido, politicamente, como um período ditatorial.

16 A intertextualidade relacionada aos pássaros negros e à cegueira será discutida com maior profundidade na segunda categoria de análise.

17 Suplemento (ISER, 2002).

18 Esse partido defendia ideias do movimentos fascista italiano e teve início durante os primeiros anos do governo de Getúlio Vargas, contestando os pensamentos esquerdistas brasileiros.

19 Nota-se que os integralistas batiam nos tambores, porém não saía som dos instrumentos". Que diabo, esses tambores não tocam?"(GUIMARÃES, 2011, p. 200).

20 A matraca substitui o sino, com seu som de madeira sobre madeira que convida ao silêncio e a reflexão. Ela é um instrumento utilizado pela igreja católica, sendo um convite à penitência e à conversão a Deus.

21 Suplemento (ISER, 2002).

\section{Referências}

AGOSTINHO, Santo. Confissões. São Paulo: Nova Cultural, 1996.

ARISTÓTELES. Poética. Porto Alegre: Globo, 1966.

BAKHTIN, Mikhail. Estética da criação verbal. Tradução Maria Ermantina Galvão. 3. ed. São Paulo: Martins Fontes, 2000.

CARVALHO, Carlos Alberto de; SANT'ANA, Guilherme Antônio Carneiro de. A tríplice mimesis como inspiração metodológica para análise de produtos culturais. Revista Consumo \& Sociedade, São Bernardo do 
Campo, v.35, n.1, p. 227-250, jul. / dez.2013. Disponível em:

https://www.metodista.br/revistas/revistas-ims/index.php/CSO/article/view/3747/3708

Acesso em: 13 fev. 2018.

CHARAUDEAU, Patrick. A conquista da opinião pública: como o discurso manipula as escolhas políticas. São Paulo: Contexto, 2016.

GRANGEIRO, Alessandra Carlos Costa. Tempo e Memória na obra de William Faulkner. 239 f. 2011. Tese (Programa de Mestrado e Doutorado em Letras e Linguística da Faculdade de Letras) - Universidade Federal de Goiás, Estado de Goiás, 2011. Disponível em:

https://repositorio.bc.ufg.br/tede/bitstream/ tde/2841/1/Alessandra_Carlos.pdf

Acesso em: 13 fev. 2018.

GUIMARÃES, Josué. Os Tambores Silenciosos. 20 ed. Porto Alegre: L\&PM, 2011.

ISER, Wolfgang. O jogo do texto. In: LIMA, Luiz Costa. A literatura e o leitor: textos da estética da recepção. São Paulo: Paz e terra, 2007. p. 105-118.

PONZIO, Augusto. A revolução bakhtiniana: o pensamento de Bakhtin e a ideologia contemporânea. São Paulo: Contexto, 2008.

RIBEIRO, Ana Paula G.; SACRAMENTO, I. Mikhail Bakhtin e os estudos da comunicação. In: (Org.). Mikhail Bakhtin: Linguagem, Cultura e Mídia. São Carlos, SP: Pedro \& João Editores, 2010. p. 9-34.

RICEUR, Paul. Tempo e narrativa, a tríplice mimese. In: . Tempo e narrativa. Tomo I. Campinas, SP: Papirus, 1994.

SAMOYAULT, Tiphaine. A intertextualidade. São Paulo: Hucitec, 2008.

SARAIVA, Juracy Assman. O estatuto do narrador. In: O circuito de memórias. São Paulo: Edusp, Nankin, 2009, p. 25-40. 